\title{
Culture as Site of Identification: Exploring Cultural Tool Normalization in Immigrant ESL Adults' Engagements with Canadian Culture
}

Roumiana Ilieva

Culture is widely acknowledged to play an important part in second-language education. This article advances a view of culture as a site of identification and introduces the notion of cultural tool normalization (CTN) to conceptualize cultural reproduction as one aspect of the multifaceted processes of identification with culture. It draws on an account of some of the author's experiences as an adult immigrant to Canada and on data from a larger study on adult ESL students' engagements with unfamiliar cultural discourses to illustrate these concepts. The article maintains that viewing culture as a site of identification and examining CTN help us to gain a more nuanced understanding of students' complicated engagements with the cultural discourses that they encounter. Such nuanced understandings should guide us in our pedagogical practices in adult ESL classrooms.

Le rôle important que joue la culture dans l'éducation en langue seconde est largement reconnu. Cet article propose une vision de la culture comme site d'identification et présente la notion de la normalisation de l'outil culturel (cultural tool normalization-CTN)) pour conceptualiser la reproduction culturelle comme un aspect de processus multidimensionnels d'identification à la culture. L'article puise dans un compte rendu de certaines des expériences de l'auteur comme immigrant adulte au Canada, et ensuite, pour illustrer ces concepts, dans des données d'une étude de plus grande envergure portant sur la participation des étudiants en ALS face aux discours culturels peu familiers. L'article maintient que l'interprétation de la culture comme site d'identification et l'étude de la CTN nous aident à mieux comprendre la participation compliquée des étudiants dans le cadre de discours culturels auxquels ils font face. Ce genre de compréhension nuancée devrait guider nos pratiques pédagogiques dans les cours d'ALS pour adultes.

\section{Introduction}

Shifting our research focus from the products of learning to its processes can be fruitful (van Lier, 2000). This article focuses on aspects of one process linked to language-learning for adult immigrants: the process of integrating into a new country / community through engagement with the culture or cultural discourses in that community. I use culture ${ }^{1}$ and cultural discourses interchangeably in this article given increasing calls in the language education 
literature to understand culture as constructed in discourses, reflecting awareness of culture's heterogeneity, conflictual nature, and power struggles over its meanings (Atkinson, 1999; Ilieva, 2005; Kramsch, 2009, 2011; Kubota, 1999; Pennycook, 2007). Similarly, I adopt a social theory perspective on discourse following Foucault's (1972) conceptualization of discourse as historically developed discursive practices that construct the objects of which they speak from a particular perspective imbued with power.

Framed another way, the process of engaging with cultural discourses was first discussed in the language education literature on acculturation (Brown, 1986; Schumann, 1978, 1986) and is present to an extent in more recent literature on culture and language teaching (Atkinson, 1999; Byram, 1989; Hinkel, 1999; Ilieva, 2001; Kramsch, 1993, 2009; 2011; Kubota, 1999; Muirhead, 2009; Taylor, 1997), as well as in literature on identity and language-learning (Block, 2007; Ibrahim, 1999; Kanno, 2003; Norton, 2000a, 2000b; Taylor, 2006). However, work in the language education literature that attempts to theorize how culture and identity are connected for languagelearners and how students engage with everyday cultural discourses available to them in and outside their classrooms would benefit from an expanded discussion of the processes that this entails. Such engagement is discussed in recent literature primarily by outlining students' agency in language-learning and use (Kramsch, 2011; Norton, 2000a). However, it seems that insufficient attention is paid to cultural reproduction in language-learning and use, which I term here cultural tool normalization (CTN). Here I advance the position that the field of language education would benefit from a more engaged focus on processes of reproduction of cultural discourses (CTN) that students experience as they integrate into a new society. Such a focus would entail adding an understanding of culture as a site of identification to the conceptualizations of culture currently operating in our field. I argue here that conceptual tools of this kind could help us better understand students' engagement with unfamiliar cultural discourses and could be useful in our pedagogical practice.

To say that culture is a site of identification implies an examination of how identities are transformed in experiences across cultures. Poststructural (Bhabha, 1994a; Butler, 1997; Hall, 1996) and psychoanalytical (Bracher, 1993; Fuss, 1995) understandings of people's engagement with culture allow us to theorize culture as a site of identification. Sociocultural work, in particular as outlined by Wertsch $(1998,2002)$, offers a lens through which to theorize the notion of CTN in order to make sense of cultural reproduction as one of the multifaceted processes of identification with culture. Cultural tool is a term used to denote the means by which individuals or agents perform a given action; cultural tools range from physical objects to theoretical constructs employed by a researcher to advance an argument, to language and discourse (Wertsch, 1998). A view of dis- 
courses as cultural tools employed by agents in performing a given action is presented below. The following brief illustration is based on some of my personal experiences as an adult immigrant to Canada, for example, how I used to and how I now construct rudeness in conversation. For some years I have been self-concerned that how I ask questions in conversations with Canadian interlocutors (in the academic environment in which I function) could be constructed as rudeness. There have been times when in my desire to fit in, I have consciously made an effort to imitate or "ventriloquate" (Bakhtin, 1981) polite formulas that I have heard around me. At other times I have refused to do this, either because it was too much of an effort for me or because I have felt the need to hold onto my accent. Sometimes also, the polite formulas circulating around me simply do not come to mind. In many cases, I ask questions that could be constructed as rude in the context of a Canadian university. I am fully aware of this, but consciously resist accepting the construction of politeness around me as the norm/mediational means / cultural tool to guide me in my interactions. It is striking, however, that for several years now there have been occasions when I interact with other Bulgarian immigrants and in the course of a conversation catch myself thinking, "Gee, this person is really rude!" I quickly rationalize my reaction, telling myself that of course this person is no ruder than before and that I am being influenced by rules of polite conversation that do not or should not apply in this context. I am puzzled that regardless of being aware that diverse "politeness" discourses dominate in varied sociocultural contexts, I unconsciously apply a construct — a cultural tool—for being polite in conversations to situations where it has no place. This cultural tool has become normal to me.

Prompted by such experiences, I explore how the normalization of a cultural tool might occur. Such exploration could allow language educators to gain a deeper understanding of their students' engagements with cultural discourses in their new language environments. In particular, awareness of cultural tool normalization can allow educators to consider the identities in which their adult immigrant students may be invested (Norton, 2000a) and thus assist language-learners in their cultural integration.

I begin with a brief review of the language education literature about language-learners' engagement with new cultures. I follow with a discussion of the theoretical frames of reference that guide me in conceptualizing culture as site of identification and the phenomenon of cultural tool normalization. I then refer to my personal experiences as an adult immigrant and introduce data extracted from a larger study on culture and texts in two adult ESL classrooms (Ilieva, 2005). I conclude with implications of this work for learning and teaching ESL to adult immigrants. 


\section{Engagement with Culture in the Second-Language Educa- tion Literature}

In second-language education, the processes of engaging with a new culture and what I term cultural tool normalization (CTN), although framed differently, were addressed initially in work on acculturation. Brown (1986) defines acculturation as "the process of becoming adapted to a new culture," which demands a "reorientation of thinking and feeling, not to mention communication" (p. 33). Notions of acculturation in language study have not changed dramatically in the last several decades (Byram, 2000). In summarizing acculturation theories, McLaughlin (1987) asserts that socio-psychological factors such as attitude toward the new language, motivation to learn, and social distance underlie the impetus toward acculturation. I problematize such cause-and-effect discussions of processes associated with cultural integration below. An important critique of acculturation theories is found in Norton's (2000a, 2000b) work; in particular, Norton's work on investment in a language as tied to a learner's identity in a given sociocultural context seems linked to the question of how language-learners engage with cultural discourses. Norton's focus is on learners' agency in struggling to gain symbolic capital and develop language congruent with their future possibilities. Agency is also the focus of Kramsch's (2011) discussion of the symbolic competence that language-learners develop when engaging with denationalized cultural resources in globalized multilingual settings. In contrast, I explore the opposite end of the continuum in the interactions of newcomers and the cultural discourses that they encounter: CTN and the question of how learners identify with the new culture.

Issues of identification became of concern to applied linguists in the early 2000s. Ibrahim $(1999,2000)$ in particular discusses how French-speaking continental African youth attending an urban Franco-Ontarian high school enter a discursive space where they are constructed and positioned as Black by dominant discourses. This has implications for their identification with African American cultural and linguistic styles, which influence what and how they learn linguistically and culturally. Questions of desire(s) as tied to identification are also being approached in second-language education literature that focuses on imagined communities that learners wish to join (Kanno \& Norton, 2003; Kramsch, 2009; Piller \& Takahashi, 2006). Desire and identification are also the focus of Mackie's (2010) work on the role of popular films in constructing ESL subjectivities. However, the question of the interplay between desires and cultural identifications as they link to the reproduction of everyday cultural discourses by language-learners (or CTN) is still undertheorized in the language education literature. In this article I attempt to shed some light on the issue. 


\section{Theorizing Culture as a Site of Identification and CTN}

Anthropology, sociology, and psychology have long histories of inquiry into how people engage with culture. Each initially searched for causes and effects in relations between "entities" such as culture and personality or individuals and society as if these were independent of one another. More recently, work conducted on how people engage with culture has been interdisciplinary in nature, challenging cause-and-effect hypotheses. I draw here on poststuctural and sociocultural works that theorize links between people and culture such as identities or identifications and practices/activities to address the dynamic nature of the culture-person relationship. Two sets of constructs are highlighted in this section: the cluster identification/desire/identity in relation to culture and the conceptualization of cultural discourses as cultural tools.

For cultural-studies theorists, media and other cultural discourses encourage us to fantasize about how we might participate in and identify with these discourses (Hall, 1996). In this context, central questions focus on how certain formulations of culture come to function as authoritative "normal" frames of reference and incite identification (Bhabha, 1994a, 1994b).

In sociocultural and poststructural appropriations of psychoanalytical theory, identification, identity, and desire are viewed as implicated in one another and linked to the cultures at hand. Thus Fuss (1995) sees desire as a type of identification and discusses the "fundamental indissociability of identification and desire" (p. 12). Bracher (1993) suggests that the various ways that culture addresses human beings is linked to the desires it evokes and/or produces in them. Below I consider the cultural identification/desire interplay in some adult ESL learners as being linked to processes of cultural reproduction of everyday cultural discourses. To make sense of such reproduction of cultural discourses, the work of the sociocultural theorist Wertsch $(1998,2002)$ is helpful in conceptualizing the notion of cultural tool normalization.

A cultural tool is a meditational means employed by agents in performing an action. There is "irreducible tension" (Wertsch, 1998, p. 25) between agents and the cultural tools that they use in activities. "Cultural tools help set the scene within which human action [occurs] and can have a powerful effect on human consciousness and action" (p. 166). Wertsch presents pictures of (a) cultural tools as both enabling and constraining human agents; and (b) human agents as both appropriating and resisting cultural tools. Agents and tools are related to each other through mastery and appropriation. Mastery refers to the skill of knowing how to use a tool with facility. Appropriation refers the act of employing a tool spontaneously and adopting particular roles and relationships with it.

I argue that cultural discourses in Foucault's (1972) sense could be regarded as cultural tools that agents employ in performing action. According to Foucault, discourses are in fact practices. Discursive practices-how we 
talk-are clearly mediational means that people employ in communication. In Foucault's theorization, discourses are power/knowledge systems in which we take up subject positions; discourses are both enabling and constraining. Wertsch (1998) claims that mediational means/cultural tools are associated with power and authority in having a potent effect on the dynamics of human action. At the same time, discourses are both producing/structuring and limiting/positioning human subjects.

The poststructural and sociocultural works briefly discussed here offer exciting explorations for second-language educators interested in engagements with culture. My discussion below illustrates various engagements with cultural discourses in Canada.

\section{Research Context}

The focus of this article is the exploration of culture as a site of identification and people's reproduction of cultural discourses. As illustrations, I present data from ESL students, together with a brief account of some of my immigrant experiences.

The student data are a small part of a larger ethnographic study that addressed various aspects of the relationships between texts and cultures in adult immigrant ESL classrooms (Ilieva, 2005). Two ESL teachers working in two separate intensive ESL programs and all their students in a three-month term took part in this study. One class consisted of 20 lower-intermediate students in a government-subsidized language class for newcomers to Canada. In the other class, 17 advanced learners were preparing for study in Canadian postsecondary institutions. The study consisted of observations in these classes, usually twice a week for about two to three hours each time, typically when classroom materials addressing life in Canada were being used. The study also involved open-ended, recorded, individual interviews with the teachers and focus-group interviews with students. In the focus groups, I enquired about students' reasons for taking the course and which aspects, if any, of culture and life in Canada they were interested in exploring in an adult ESL classroom. I introduced myself to both classes as a graduate student and an immigrant like themselves, who on the basis of personal experiences with immigration felt "strongly that culture should be a part of an ESL classroom [and who was] just curious to know how [they themselves] feel about this" (AT 25.10.00).

\section{Cultural Tool Normalization: Illustrative Examples}

In this section, I discuss personal experiences as well as some adult ESL students' engagements with cultural discourses in a metropolitan Canadian city. I explore these engagements to address the interplay between desires and cultural identifications as linked to the reproduction of cultural discourses that surround newcomers. To make sense of some of my personal experi- 
ences as an immigrant to Canada, I found Haug's $(1987,1992)$ perspective useful. Haug (1987) insists on the need to reflect on past events and situations in order to discover how "individuals construct themselves into existing social relations" (p. 33) and suggests that the analyzed experience of individuals could contribute to the formation of theory.

\section{Personal Experiences and CTN}

I first developed a concern with culture as a result of my personal experiences as an adult immigrant to Canada. As a fluent speaker of English and an EFL teacher for a number of years in my native country, I was surprised and disconcerted to find out early in my residence in Canada that I routinely committed cultural gaffes such as, for example, offering long and detailed responses to the common question How are you? As I entered North American academia as a graduate student, I felt the need to explore a topic that although it focused on educational issues, would address some of the challenges that I experienced in my daily life. In focusing on how Canadian culture is presented in texts designed for adult learners of English, I hoped that I would learn what was deemed important to communicate to immigrants like myself. Reading through many textbook units during this period, I remember feeling angry with and alienated from the topics and characters in them. I was disappointed in these texts because although they presented information on Canadian geography, history, and sports, they did not appear to present cultural knowledge that would help me in my everyday interactions with Canadians. I did not see in them immigrants like myself struggling to make sense of the cultural discourses around them. What angered me was what I perceived as "factual" information that did not invite students to negotiate their understandings of it (see Ilieva, 2000, for a more detailed account). Interestingly, however, when I went back to those same texts several years later, I wondered what I had found wrong with many of them; I realized that I could no longer rely on my reactions as a "new" immigrant interacting with texts to guide me in analyzing them. I now read many of these same texts as normal in how they presented Canadian culture. In my later interactions with these texts, I brought to them everyday cultural discourses with which I had become familiar and that were in the texts themselves. I see in the normalcy of these texts a reproduction on my part of cultural discourses.

One example of such a normalized discourse in many of these texts is a more consumerism-oriented approach to life than I had previously experienced. For example, a significant number of texts focused at length on entertainment activities such as eating out, going to a ball game, shopping, and outdoor activities. I came to Canada in the early 1990s from an ex-communist country where the basic necessities of life were available, but abundance and variety of goods, foods, or entertainment would be considered frivolous. One text, for example, "Community Contact Tasks" to assist adult ESL students 
with cultural integration in Canada included: "The Party Clothes Task; The Fruit Task; The Crunchy Munchy Task; The Dairy Task; The Junk Food Task; The Fast Food, Junk Mail Task; The Bank Task; The Y [YMCA/YWCA]; The Recycling Task" (Berish \& Thibaudeau, 1992, p. 141). In my view, all but the Bank Task and the Recycling Task promoted consumerism. An excerpt from the first task above instructed students: "Go to a department store or a clothing store. Put together an exciting outfit that you would like to wear to a fancy party" (p. 142). My initial reaction to such a task almost 20 years ago was rejection of the frivolity that it entailed for me. However, with many occasions since then to prepare for and attend Halloween parties, such a task now seems somewhat normal.

Reflecting on my experiences, I became aware that the discourses / cultural tools from which I had initially felt alienated had imperceptibly become normal to me. In considering my own story, I focus on myself as agent and my relationship to texts and the discourses embedded in them. Wertsch (1998) maintains that agents and tools are related to each other through mastery and appropriation, and he offers examples suggesting that appropriation ranges from actively embracing to strongly resisting a cultural tool. In a section entitled "Mastering Historical Texts: Knowing Too Much," Wertsch describes his study of texts produced by college history students about the origins of the United States.

One of the most striking facts about [the students'] texts is that all of them are fundamentally grounded in the [official] quest-for-freedom narrative tool. No matter how much or how little the subjects [sic] seemed to accept and agree with this narrative tool, they all used it in one way or another. (pp. 107-108, italics in original)

Wertsch concludes that regardless of whether they resisted it or embraced it, all students had mastered this cultural tool and in this sense, "were highly constrained in what they could say" (p. 108). Clearly, as Wertsch suggests, "agents always employ cultural tools provided by particular sociocultural settings" (p. 109), but most important is the pervasiveness of a specific cultural tool in a particular setting. Cultural tool normalization is closely related to the mastery (i.e., employment with facility) of a tool, which seems affected by the dominance in a sociocultural context of this tool over others that could be employed for similar purposes.

Thus one reason why I may have come to see as normal the texts about Canadian culture designed for ESL adults that I had initially rejected could be the pervasiveness in society of the discourses embedded in them. In my everyday life, I am increasingly in situations where Canadian discursive practices/cultural tools are the norm. This makes it difficult for me not to be "socialized into appropriating" (Wertsch, 1998, p. 175) them. As well, the cultural tools for making sense of the world, which I had acquired before com- 
ing to Canada, are no longer readily available in my new environment. As is evident from the example about rudeness referred to in the introduction, I use some of these Bulgarian tools to an extent when interacting with Canadians, but I am acting in "the space of the other" (de Certeau, 1984, p. 37) in these circumstances. The limited times and spaces of my conversations with other Bulgarian immigrants in which cultural tools appropriated in childhood can be used constrain the possibility for their use outside this context. So I see cultural tool normalization as tied to access to-and the pervasiveness and possibilities for mastery and appropriation of-given cultural tools/discourses in my life contexts.

Reflecting on my immigrant experiences also helped me to identify the ambiguity that I experienced in trying to pinpoint my attitude toward discourses on culture in the texts that I investigated. Before writing about my experiences, I felt that I could easily say that I had consciously rejected these texts. I later realized that my desire to fit into the Canadian environment made matters much more complicated. I was left wondering whether or how my normalization of these texts could have been affected by my eagerness/desire for integration. I was led to explore whether other adult ESL immigrants had had similar experiences and how they engaged with cultural discourses in their new environment.

Adult ESL Students and CTN refers to processes of reproducing cultural discourses and for me was tied to access to, and pervasiveness of and possibilities for, mastery and appropriation of cultural tools in the Canadian context. My personal story, used as a springboard for theorizing (Haug, 1992), illustrates my strong initial desire to integrate into Canadian society. I wanted to explore the desires operating in adult ESL students' engagement with particular discourses available to them and to investigate further the conceptualization of culture as a site of identification and cultural tool normalization.

To learn more about CTN, I asked all the students in my study whether they had changed in how they thought about important matters in their lives since coming to Canada. As the data below suggest, evidence of CTN in some of the advanced students' engagement with Canadian culture was not found in the interviews with the lower-intermediate students. I discuss views shared by the advanced students followed by those of the lower-intermediate students. I have selected responses from only two advanced students, as these lend themselves to a deeper theorizing of CTN. Others also shared their experiences of change since coming to Canada; however, most offered brief responses that did not allow me to explore their processes of CTN in greater detail. One of the limitations of my study has been the impossibility of engaging with processes of CTN that directly involve engagement with discourses specifically available in the classrooms settings that I observed. Given the short duration of these courses, the time I was in these classrooms, and the fact that the students then moved on to other endeavors or further 
courses, makes it unreasonable to trace reproduction of classroom cultural discourses by specific students. The insights I gained into processes of CTN for the few students who told of their desires for integration into Canadian society could be valuable in providing language educators with avenues to explore with their immigrant students.

For example, Jessica, an advanced student in her early 40s who came to Canada with her young family over eight years ago and was working as a designer at the time of this study shared the following.

I think [I've changed with respect to] the concept of parents. The first time I heard when they say what the parents should be in Canada, I didn't accept that, I refuse that.... Because, for example, my Chinese2 [parenting] style, and they say all the parents have to care for the kids even after they grow up, finish university and then they have to care for marriage ... they have to care for them until the parents die. Here it's very different, and they say after you go out, maybe at 18 or something, you can go wherever you want ... In the beginning I cannot accept that, I say, how can the parents [be] like that? [laugh] They don't care, they are cruel ... After I live for 2 or 3 years and then ... I make sense and now I think that's right. (SI 27.03.01)

This excerpt illustrates a change that Jessica experienced in how she constructs parenting. Whereas when she first came to Canada, she believed that the parents' role was to be actively involved in their child's life until death, she now takes a view more consistent with what she experienced as the cultural discourse of parenting here in Canada. She now seems to accept a discourse that I would characterize as more laissez-faire parenting. I was able to trace how this change happened for Jessica.

Most of [the Canadian ideas] I learnt from school. I talk to the teacher, practice my speaking, and then I learn more, a lot, their idea, the concept ... I understand it why Canadian do it like that. From teacher I learn a lot. (SI 27.03.01)

Jessica's engagement in talk with a Canadian teacher for the purpose of practicing her English has led to mastery (Wertsch, 1998) of a given cultural discourse on parenting: she can use the discourse with facility. She also seems to have appropriated this cultural tool with enthusiasm, as she now considers it the "right" kind of parenting. In other words, she seems to consider it normal to apply this tool in her identity/position as a parent.

Actually after I learn more and more and then I accept the Canadian style, the parents' style and then ... I change the attitude to my son. Before that I, like my parents, I say, “Okay, you can't go out, stay 
here, do your homework until it is done." Right now I try to use the Canadian style, more friendly talk to him and play a game a while and then let him feel happy and confident and do his homework.... The Chinese parents have to learn that; I think it's very important. (SI 27.03.01)

Jessica seems to have changed her style of parenting: instead of dictating how her son approaches tasks, she negotiates with him and makes sure that he feels good about them. She calls this "the Canadian style" that Chinese parents need to follow. Wertsch's (2002) work shows that cultural tool appropriation "may serve as an identity resource" (p. 120), and I am interested here in what seems to be the wholehearted appropriation of what Jessica perceives to be Canadian-style parenting. (Bracher, 1993), taking a psychoanalytical stance, points out:

Discourses that get us to change our position are dis $\neg$ courses that coerce us to give up some of our [master signifiers/positionings] and/or embrace new ones often in order to retain and solidify the services of others that are even more central to [us]. (pp. 27-28)

Bracher explains that "master signifiers" are any of those that define us for ourselves and for others, such as man, woman, loving parent, dumb, smart, professional, service worker, and so forth. Ibrahim (1999) explains that such definitions are not fixed markers of oneself, but rather positionings that depend on the discursive, sociopolitical, and sociocultural practices in which one is situated at a given time. Jessica seems willing to abandon the master signifiers/positionings with which she has lived, exemplifying that what she constructs as Chinese-style parenting (i.e., firm and imposing parenting) for what she perceives as the master signifiers of Canadian-style parenting (i.e., friendly attitude) because even more central to her is the identity of a loving parent in the new cultural discourses that she encounters. Loving parent is constructed here as one open to negotiating activities given a child's wishes, and she embraces and begins to identify with this local/new cultural discourse.

Another example of the process of CTN is illustrated in the immigrant experiences of advanced student Lorna, a high school student who came to Canada with her parents about two years earlier. She was focusing on upgrading her English skills and graduating from high school to become a nurse.

[I've changed] for sure ... I think it's really different 'cause in the Philippines ... ambition is not really something that [girls] think about.... [There] usually ... after you, like, graduate in high school and you got married, for example, you usually stick at the house, you usually take care of the kids and things like that ... but here, um, 
you can see the difference 'cause women here are career oriented, they think more about ... their life, what they want, it's not always like, you know, family, settling down... Here it's always the career that comes first. (SI 29.03.01)

Unlike before, when she lived in the Philippines and considered a woman's place to be in the home, Lorna now seems to perceive it as normal for a woman to have career ambitions. It seems that the presence of what she observes as independence around her accounts for this change in her views.

When I got here it's different 'cause I've seen like people so independent ... especially the Canadians. And those Filipinos who grow overseas here in Canada, they are so independent. And so when I came I was like so shocked it's like the adjustment ... from being dependent to trying to be independent.... until now I am still adjusting but I am focused on my career because I really want to be independent. (SI 29.03.01)

This excerpt suggests that in observing and engaging with people in Canada, especially with people of Filipino origin, Lorna comes to see them as independent. Lorna's desire to become independent can also be noted in the excerpt. Given the discursive production of desires (Ibrahim, 1999; Mackie, 2010), it is possible that the pervasiveness of independence as a cultural tool employed by many women in the Canadian context may have led to this desire. As Bracher (1993) asserts, "in coming to embody certain [master] signifiers [in a given sociopolitical and discursive setting], [a] subject also adopts certain specific desires" (p. 30). Thus perhaps it is Lorna's desire to embody the master signifier/positioning independent that she sees all around her that leads to her desire to become a career woman. As she states, it is because she wants to be independent that she sets career goals. Thus independence and $c a-$ reer woman seem linked in her engagements with Canadian culture and how she attempts to integrate.

Although these instances of CTN could be seen in the interviews with some of the advanced students, no such indications of cultural tool normalization appeared in the interviews with lower-intermediate students. However the desire of some of these students to change can be observed. When asked if they had changed since coming to Canada, Virginia, a lower-intermediate student in her early 30s focused on upgrading her English skills, told me:

I think I need to change. In here very difficult operate.... It's strange Canadian conversation, communication different, if I change my thinking, maybe I can conversation with other people. (SI 13.12.00) 
This excerpt shows Virginia's perception of the need to change if she wishes to converse with Canadians; she currently finds it difficult to communicate with the people around her. Similarly, another student, Vanessa, a lower-intermediate student in her late 20s who was a homemaker at the time of the study stated earnestly, "I should change. [I am in a] new situation, need to change my mind" (SI, 23.11.00).

How might we account for the desire of these and other less languageproficient immigrants to change their way of thinking (and talking) in their attempts to integrate into Canada? In each individual there seems to be a desire for an identity in which one can recognize oneself and be recognized by others (Bracher, 1993; Norton, 2000a) in a community with specific sociocultural and discursive practices. If low-proficiency ESL speakers routinely encounter Canadians who speak only English, there will probably be limited opportunities for recognizing the identity positions with which these immigrants have lived for years in other settings in other discursive practices. What are they then left with in order to fulfill the desire to be recognized other than to attempt to identify with Canadians whom they meet in their new environment? At the same time, however, desire as a type of identification, "is precisely a desire to be a subject" (Borch-Jacobsen, 1991, cited in Fuss, 1995, p. 12). Butler (1997) explains,

Bound to seek recognition of its own existence in categories ... and names that are not of its own making, the subject seeks the sign of its own existence outside itself, in a discourse that is at once dominant and indifferent. (p. 20)

Thus for ESL learners with a limited command of the language in the unfamiliar Canadian environment they now inhabit, the desire to be recognized may give rise to the desire to change their thinking, to master some of the new cultural discourses/tools that they encounter. This is a process that may also trigger discourse appropriation and CTN/cultural reproduction on the path to cultural integration. Norton (2000a) shows that a desire to be recognized in a particular identity position (e.g., a mother) affects an immigrant's investment in learning English and thus engagement with the cultural discourses in his or her integration process.

\section{Implications for Practice}

The conceptual tools advanced here and the data that illustrate them offer insights into how some new Canadians position themselves in the cultural discourses that surround them. Such insights are important for languagelearning classrooms given that these settings are much more than sites for acquiring a linguistic code. Adult immigrant ESL learners' engagement with new cultural discourses/tools in new settings is likely to involve mastery 
and (resisting or embracing) appropriation of these discourses that imply changes in learners' identities.

Classrooms provide cultural tools / discourses that affect which identities are possible for students and how these relate to identities that have previously been available to them (Kramsch, 2009; Norton, 2000a). In this context, teachers and students should become aware of the discursive nature of culture (Kubota, 1999) and in the process of language-learning, build on the experiences, identities, and desires that students bring with them and acquire in their new environment. Classroom discussions of the complex struggles and hopes of new immigrants in their engagements with cultural discourses in Canada could foster deeper understandings of cultural integration processes for both educators and students. For successful language-learning, educators need to consider creating conditions that allow adult learners to deal comfortably with the conflicts of living in more than one language and culture. This is an important task given Canagarajah's (2004) claim that resolving conflicts of inhabiting competing subject positions in diverse discourse communities is "at the heart of becoming a successful language learner" (p. 117). Classrooms could be spaces where learners can attempt to negotiate the conflictual discourses that they inhabit and with which they desire to identify. As Wenger (1998) points out, "reconfiguring relations of identification and negotiability is as significant for learning as is access to specific pieces of information" (p. 220). Ultimately, if identification is the link connecting cultural discourses to identities (Oswell, 2006), deeper understandings of processes of cultural engagement can facilitate classroom practices based on the premise that the aim of learning is the fulfillment of personal needs and desires (of being) and that any ESL pedagogy not culminating in these is bound to fail (Ibrahim, 1999).

\section{Concluding Remarks}

In this article, I explore processes rather than products that could be linked to learning and using a language by newcomers to a country. I outline some conceptual tools and offer glimpses into how newcomers engage with Canadian cultural discourses in the process of cultural integration by treading the complex territory of culture as a site of identification and cultural tool normalization. This territory remains under-theorized in our field when questions of cultural integration do not specifically focus on students' agency in language-learning processes.

This article extends work in the field of language education and the phenomenon of cultural identifications and desires in language-learners (Ibrahim, 1999; Kramsch, 2009; Mackie, 2010; Norton, 2000a) by expanding on processes of cultural reproduction that have not received sufficient attention in the literature. I hope the article unsettles further theories of acculturation, as I employ constructs that offer more nuanced insights into how people and culture 
interrelate when "reorientation of thinking and feeling" are required (Brown, 1986, p. 33). Overall, the story of how some adult ESL students engage with the cultural discourses that they encounter illustrates powerfully that culture as a site of identification is complex and can lead to ambivalent identifications. Some theories of acculturation claim that people reorient their thinking and behavior by following a set trajectory of cultural integration. This exploration, on the other hand, suggests that individuals engage with new cultural discourses and develop mastery and appropriation in a variety of ways. The processes are individually unique, and the areas in which they undertake identification with new cultural discourses in Canada are probably associated with specific desires and strong identity positions. They may already hold these from their home country (e.g., Jessica) or develop desirable identity positionings in discourses that are easily accessible in Canada (e.g., Lorna).

In addition, the desire to change/fit in/integrate evident in the words of some of the lower-intermediate students (and to an extent in my personal story) seems tied to the students' new sociocultural contexts rather than to any particular individual attitude toward the language that they are learning, as proponents of acculturation might claim. This work confirms an observation about cultural integration made elsewhere, in which integration is viewed as a fluid process "involving a multiplicity of spheres of experience" (Spitzer \& Torres, 2008, p. 5). Longitudinal exploration of the cultural discourses with which adult ESL immigrant learners engage inside and outside language classroom settings is recommended. More focus is needed on the effect of these discourses on processes of CTN/cultural reproduction and identity positions for immigrants during their cultural integration.

\footnotetext{
Notes

${ }^{1}$ The term culture has been notoriously difficult to define, and since the 1990s works in language education have outlined inconsistencies in conceptualizations of culture and drawn our attention to culture's heterogeneity, multivocality, contradictions, and conflicts in and across traditionally perceived national or ethnic boundaries (Atkinson, 1999; Ilieva, 2000, 2001; Kramsch, 1993; Kubota, 1999). Although I have used the term elsewhere (Ilieva, 2005) to reflect the fact that culture is a site of contestation and struggle over meanings of people with various identities and positions of power, I choose to use the more generic term culture here as it is still used in the field (a recent example is Walsh-Marr, 2011). My use is a short way of referring to a powerful force in human life that needs to continue to be theorized on various levels. To be able to engage in more refined theorizing about culture as it relates to language education here, I felt that a more cumbersome construct might overcomplicate matters.

${ }^{2}$ The discussion on "Chinese" style parenting or "Canadian" style parenting should not be interpreted to mean that I believe that such discourses can be clearly identified or seen as generalizable and endorsed by all Chinese or Canadian people. The fact remains, however, that our students continue to use such shorthand terms to represent their own experiences of difference. I attempt to specify in the discussion that these are the personal perceptions of the study participants. I also hope that the occasional substitution of these terms with a term like Canadian cultural discourses about parenting, independence, and so forth offers an understanding of cultural discourses as multiple and sites of contestation given my endorsement of Foucault's view of discourse.
} 


\section{Acknowledgments}

I gratefully acknowledge an SSHRC doctoral fellowship that funded the study described in this article. I also thank Kelleen Toohey and June Beynon for their encouragement and comments on earlier drafts of this article; Marian Rossiter for her support; and the anonymous reviewers for their constructive suggestions.

\section{References}

Atkinson, D. (1999). TESOL and culture. TESOL Quarterly, 33, 625-654.

Bakhtin, M.M. (1981). The dialogic imagination: Four essays (C. Emerson \& M. Holquist, Trans.). Austin, TX: University of Texas Press.

Berish, L., \& Thibaudeau, S. (1992). Canadian Concepts 4. Scarborough, ON: Prentice-Hall Canada.

Bhabha, H.K. (1994a). The location of culture. New York: Routledge.

Bhabha, H.K. (1994b). Remembering Fanon: Self, psyche and the colonial condition. In P. Williams \& L. Chrisman (Eds.), Colonial discourse and post-colonial theory: A reader (pp. 112123). New York: Columbia University Press.

Block, D. (2007). Second language identities. New York: Continuum.

Bracher, M. (1993). Lacan, discourse, and social change: A psychoanalytic cultural criticism. Ithaca, NY: Cornell University Press.

Brown, H.D. (1986). Learning a second culture. In J. M.Valdes (Ed.), Culture bound: Bridging the cultural gap in language teaching (pp. 33-48). Cambridge, UK: Cambridge University Press

Butler, J. (1997). Excitable speech: A politics of the performative. New York: Routledge.

Byram, M. (1989). Cultural studies in foreign language education. Clevedon, UK: Multilingual Matters.

Byram, M. (Ed.). (2000). Routledge encyclopedia of language teaching and learning. New York: Routledge.

Canagarajah, S. (2004). Subversive identities, pedagogical safe houses, and critical learning. In B. Norton \& K. Toohey (Eds.), Critical pedagogies and language learning (pp. 116-137). Cambridge, UK: Cambridge University Press.

de Certeau, M. (1984). The practice of everyday life. Berkeley, CA: University of California Press.

Foucault, M. (1972). The archaeology of knowledge (A.M. Sheridan Smith, Trans.). London: Tavistock.

Fuss, D. (1995). Identification papers. New York: Routledge.

Hall, S. (1996). Introduction: Who needs "identity"? In S. Hall \& P. du Gay (Eds.), Questions of cultural identity (pp. 1-17). London: Sage.

Haug, F. et al. (1987). Female sexualization: A collective work of memory (E. Carter, Trans.). London: Verso.

Haug, F. (1992). Beyond female masochism: Memory-work and politics. London, UK: Verso.

Hinkel, E. (Ed.). (1999). Culture in second language teaching and learning. Cambridge, UK: Cambridge University Press.

Ibrahim, A. (1999). Becoming Black: Rap and hip hop, race, gender, identity, and the politics of ESL learning. TESOL Quarterly, 33, 349-369.

Ibrahim, A. (2000). Identity or identification? A response to some objections. TESOL Quarterly, $34,741-744$.

Ilieva, R. (2000). Exploring culture in texts designed for use in adult ESL classrooms. TESL Canada Journal, 17, 50-63.

Ilieva, R. (2001). Living with ambiguity: Toward culture exploration in second language classrooms. TESL Canada Journal, 19, 1-15.

Ilieva, R. (2005). A story of texts, culture(s), cultural tool normalization, and adult ESL learning and teaching. Unpublished doctoral dissertation, Simon Fraser University. 
Kanno, Y. (2003). Negotiating bilingual and bicultural identities: Japanese returnees betwixt two worlds. Mahwah, NJ: Erlbaum.

Kanno, Y., \& Norton, B. (2003). Imagined communities and educational possibilities: Itroduction. Journal of Language, Identity, and Education, 2(4), 241-249.

Kramsch, C. (1993). Context and culture in language teaching. Oxford, UK: Oxford University Press.

Kramsch, C. (2009). The multilingual subject. Oxford, UK: Oxford University Press.

Kramsch, C. (2011). The symbolic dimensions of the intercultural. Language Teaching, 44, 354367.

Kubota, R. (1999). Japanese culture constructed by discourses: Implications for applied linguistics research and ELT. TESOL Quarterly, 33, 9-35.

Mackie, A. (2010). Me Tarzan, you Jane: Desire and identity in popular films with ESL. Germany: Lambert Academic.

McLaughlin, B. (1987). Theories of second-language learning. London: Edward Arnold.

Muirhead, P. (2009). Rethinking culture: Toward a pedagogy of possibility in world language education. Critical Inquiry in Language Studies, 6(4), 243-268.

Norton, B. (2000a). Identity and language learning: Gender, ethnicity and educational change. London: Longman.

Norton, B. (2000b). Investment, acculturation, and language loss. In S.L. McKay \& S.C. Wong (Eds.), New immigrants in the Unites States: Readings for second language educators (pp. 443461). Cambridge, UK: Cambridge University Press.

Oswell, D. (2006). Culture and society: An introduction to cultural studies. London: Sage.

Pennycook, A. (2007). Global Englishes and transcultural flows. New York: Routledge.

Piller, I., \& Takahashi, K. (2006). A passion for English: Desire and the language market. In A. Pavlenko (Ed.), Bilingual minds: Emotional experience, expression and representation (pp. 5983). Clevedon, UK: Multilingual Matters.

Schumann, J. (1978). The acculturation model for second-language acquisition. In R. Gingras (Ed.), Second language acquisition and foreign language teaching (pp. 27-50). Washington, DC: Center for Applied Linguistics.

Schumann, J.H. (1986). Research on the acculturation model for second language acquisition. Journal of Multilingual and Multicultural Development, 7, 379-392.

Spitzer, D., \& Torres, S. (2008). Gender-based barriers to settlement and integration for live-in caregivers: A review of the literature (CERIS Working Paper No. 71). Available: http://ceris.metropolis.net/Virtual\%20Library/WKPP\%20List/WKPP2008/CWP71.pdf

Taylor, L. (1997). "Canadian culture," cultural difference, and ESL pedagogy: A response to Robert Courchêne and Virginia Sauvé. TESL Canada Journal, 15, 70-76.

Taylor, L. (2006). Cultural translation and the double movement of difference in learning "English as a Second Identity." Critical Inquiry in Language Studies, 3(2/3), 101-130.

van Lier, L. (2000). From input to affordance: Social-interactive learning from an ecological perspective. In J.P. Lantolf (Ed.), Sociocultural theory and second language learning (pp. 245260). Oxford, UK: Oxford University Press.

Walsh-Marr, J. (2011). Keeping up the conversation on culture: A response to Robert Courchêne and others. TESL Canada Journal, 29, 113-120.

Wenger, E. (1998). Communities of practice: Learning, meaning, and identity. Cambridge, UK: Cambridge University Press.

Wertsch, J.V. (1998). Mind as action. New York: Oxford University Press.

Wertsch, J.V. (2002). Voices of collective remembering. Cambridge, UK: Cambridge University Press. 